\title{
Phragmalin-Type Limonoid Orthoesters from Chukrasia tabularis var. velutina
}

\author{
Jun Luo, Jun-Song WANG, Xiao-Bing WAng, Jian-Guang Luo, and Ling-Yi KonG* \\ Department of Natural Medicinal Chemistry, China Pharmaceutical University; 24 TongJiaXiang, Nanjing 210009, \\ People's Republic of China. \\ Received September 2, 2010; accepted November 3, 2010; published online November 16, 2010
}

\begin{abstract}
Nine new phragmalin-type limonoid orthoesters, tabulalides $\mathrm{F}-\mathrm{N}(1-9)$, together with three known compounds, tabulalides $\mathrm{C}$ and $\mathrm{D}$, and tabularisin $\mathrm{N}(10-12)$, were isolated from the stem bark of Chukrasia tabularis var. velutina. Extensive spectroscopic technologies were applied to elucidate the structures of these new compounds, including the application of circular dichroism (CD) exciton chirality method for the determination of the absolute configurations of 1 and 2. Tabulalide $F$ (1) has a rare orthoisobutylate moiety in phragmalin-type limonoid orthoesters. These compounds were evaluated for cytotoxic activity against five human cancer cell lines in vitro. Tabulalide $\mathrm{G}(2)$ exhibts moderate cytotoxic activity against MCF-7 with $\mathrm{IC}_{50}$ value of $20.4 \mu \mathrm{mol} / \mathrm{l}$, and other compounds have weak inhibitory effects on the growth of tested tumor cells.
\end{abstract}

Key words phragmalin-type limonoid; orthoester; Chukrasia tabularis var. velutina

The orthoester group contains a carbon atom bearing three alkoxy or aryloxy groups, and, combined with additional attachments and/or rings, constructs often various structural skeletons of stereochemical complexity, such as daphnane diterpenoids, phragmalin-type limonoids, and bufadienolide and ergostanoid steroids, some of which showed anticancer, antifeedant, and insecticidal activities. ${ }^{1)}$

Phragmalin-type limonoid orthoester is an important branch of orthoesters with phragmalin limonoid as the basic skeleton, discovered exclusively from the genera of Meliaceae. ${ }^{1,2)}$ The genus chukrasia (Meliaceae) ${ }^{3)}$ was revealed to be a rich resource of structure diversified phragmalin-type limonoids as well as orthoesters. ${ }^{4-9)}$ Our previous study on phragmalin-type limonoids from Chukrasia tabularis var. velutina afforded a series of 16-norphragmalin limonoids ${ }^{10,11)}$ and a new class of C-15-acyl phragmalin-type limonoids orthoesters. ${ }^{12)}$ In our present research, nine new phragmalintype limonoid orthoesters, tabulalides $\mathrm{F}-\mathrm{N}(\mathbf{1}-\mathbf{9})$, together with three known compounds, tabulalides $\mathrm{C}$ and $\mathrm{D}$ and tabularisin N (10-12), were isolated from the ethanol extract of this plant. The structures of these new compounds (Fig. 1) were elucidated using extensive $2 \mathrm{D}$ spectroscopic technologies, and the absolute configurations of $\mathbf{1}$ and $\mathbf{2}$ were determined by circular dichroism (CD) exciton chirality method. ${ }^{1,13)}$ Tabulalide F (1) possesses a rare orthoisobutylate moiety in phragmalin limonoid orthoesters.

Anticancer activity is the important aspect of limonoids from Meliaceae, and a precursor of phragmalin limonoid was found to be a novel Hsp90 inhibitor. ${ }^{14,15)}$ So, we evaluated cytotoxic activity of compounds $\mathbf{2}-\mathbf{1 2}$ against five human cancer cell lines, MCF-7 (human breast cancer), Hela (human cervical cancer), SGC-7901 and BGC-823 (human gastric cancer), HepG2 (human liver cancer). The preliminary results indicated that compund $\mathbf{2}$ exhibts moderate cytotoxic activity against MCF-7 with $\mathrm{IC}_{50}$ value of $20.4 \mu \mathrm{mol} / 1$ and weak cytotoxic activity against SGC-7901 with $\mathrm{IC}_{50}$ value of $63.4 \mu \mathrm{mol} / 1$. The other isolates show weak cytotoxic activity or noncytotoxic $\left(\mathrm{IC}_{50}>100 \mu \mathrm{mol} / \mathrm{l}\right)$ anainst other cancer cell lines. Herein, the isolation, structural elucidation, and cytotoxic activity of these isolates were reported.

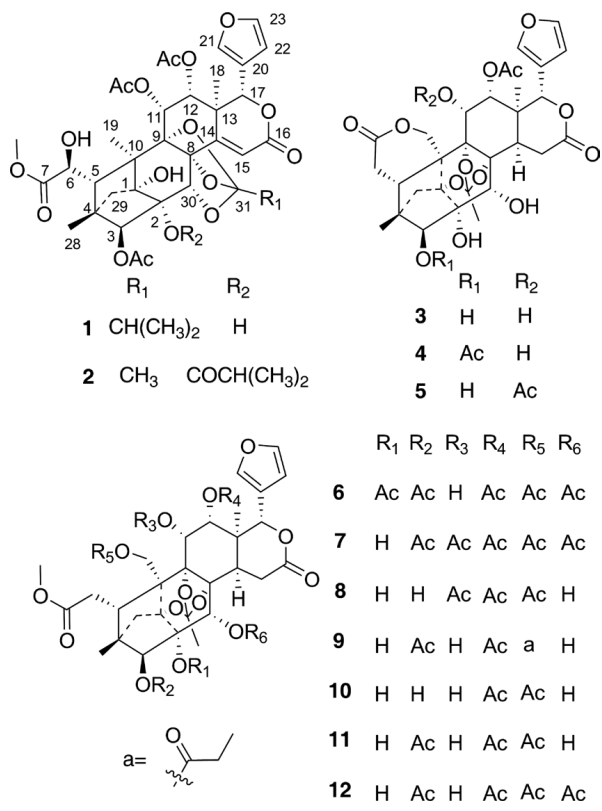

Fig. 1. The Structures of Compounds $\mathbf{1}-\mathbf{1 2}$

\section{Results and Discussion}

Tabulalide F (1) was isolated as white amorphous powder. Its molecular formula was established to be $\mathrm{C}_{38} \mathrm{H}_{44} \mathrm{O}_{17}$ by the high resolution-electrospray ionization (HR-ESI)-MS ion at $m / z 783.2470[\mathrm{M}+\mathrm{Na}]^{+}$(Calcd: $\mathrm{C}_{36} \mathrm{H}_{44} \mathrm{O}_{16} \mathrm{Na}, 783.2471$ ). The IR absorption bands at 3499, 1737 and $1641 \mathrm{~cm}^{-1}$ suggested the presence of hydroxyl, ester, and $\alpha, \beta$-unsaturated ester carbonyl groups. The data from decoupling and subsequent $1 \mathrm{D}$ - and 2D-NMR studies $\left({ }^{1} \mathrm{H},{ }^{13} \mathrm{C}\right.$, heteronuclear multiple bond connectivity (HMBC), heteronuclear single quantum coherence (HSQC), and rotating frame Overhauser enhancement spectroscopy (ROESY)) (Fig. 2) revealed the presence of some characteristic moieties of phragmalin-type limonoid, such as a $\beta$-substituted furanyl ring $\left(\delta_{\mathrm{H}} 6.54,7.40\right.$, and $7.40 ; \delta_{\mathrm{C}} 121.0,110.2,143.1$, and 142.0), characteristic 4, 29, 1-ring bridge $\left[\delta_{\mathrm{H}} 1.75(\mathrm{~d}, J=11.0 \mathrm{~Hz})\right.$ and $2.29(\mathrm{~d}$, $\left.J=11.0 \mathrm{~Hz}) ; \delta_{\mathrm{C}} 40.3\right]$, and the methyl esterified C-6-C-7 appendage, which suggested that 1 was a phragmalin-type 


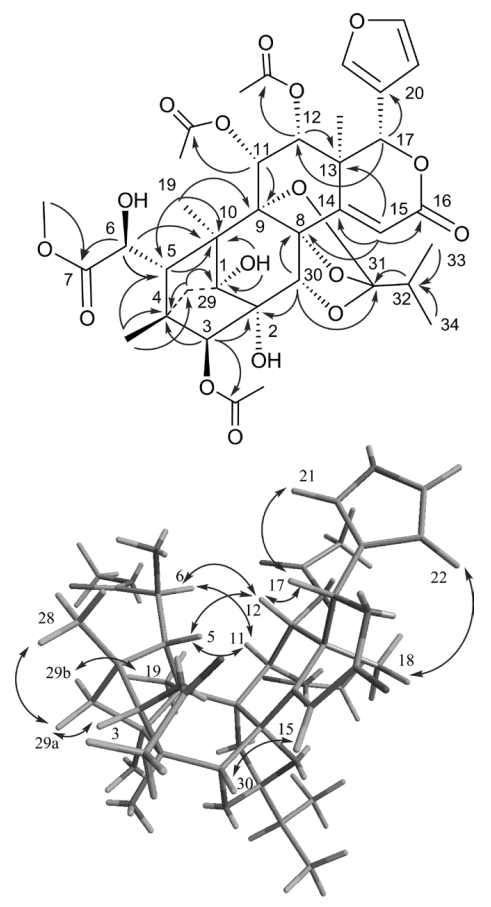

Fig. 2. Key HMBC and ROESY Correlations of $\mathbf{1}$

limonoid. ${ }^{10-12)}$ The HMBC correlations from a downfield signal at $\delta_{\mathrm{H}} 6.47$ to quaternary carbons at $\delta_{\mathrm{C}} 163.3(\mathrm{C}-16)$, $\delta_{\mathrm{C}} 151.8(\mathrm{C}-14), \delta_{\mathrm{C}} 83.8(\mathrm{C}-8)$, and $\delta_{\mathrm{C}} 42.0$ (C-13) suggested that this proton was the olefinic $\mathrm{H}-15$ and the $\mathrm{D}$ ring of 1 was a $\Delta^{14,15)} \alpha, \beta$-unsaturated $\delta$-lactone ring. ${ }^{16)}$ A single proton signal at $\delta_{\mathrm{H}} 5.19$ was assignable to H-6 by its correlations observed in the HMBC spectrum with quaternary carbon signals at $\delta_{\mathrm{C}} 174.5(\mathrm{C}-7), \delta_{\mathrm{C}} 45.9(\mathrm{C}-5), \delta_{\mathrm{C}} 44.1(\mathrm{C}-4)$, and $\delta_{\mathrm{C}} 48.2(\mathrm{C}-10)$, which suggested that $\mathrm{C}-6$ has been oxygenated. A typical orthoester carbon signal at $\delta_{\mathrm{C}} 123.0$ showing $\mathrm{HMBC}$ correlations with proton signals of an isopropyl group $\left[\delta_{\mathrm{H}} 2.20(\mathrm{~m}, 1 \mathrm{H})\right.$, and $\left.\delta_{\mathrm{H}} 1.10(\mathrm{~d}, J=7.6 \mathrm{~Hz}, 6 \mathrm{H})\right]$, suggesting the orthoester moiety in $\mathbf{1}$ is an isobutylate group, rarely encountered in phragmalin orthoesters. ${ }^{2,16)}$ A proton signal at $\delta_{\mathrm{H}} 3.28$, no correlation with carbon observed in HSQC spectrum, showed HMBC correlations with carbon signals at $\delta_{\mathrm{C}} 84.6(\mathrm{C}-1), \delta_{\mathrm{C}} 48.2(\mathrm{C}-10)$, and $\delta_{\mathrm{C}} 40.3(\mathrm{C}-29)$, which suggested that it is a hydroxy proton singal and attached at $\mathrm{C}-1$. The presence of the $\mathrm{OH}$ group at $\mathrm{C}-1$, the weak HMBC correlation from $\mathrm{H}-30\left(\delta_{\mathrm{H}} 4.51\right)$ to the orthoester carbon, and the chemical shifts of C-2 $\left(\delta_{\mathrm{C}} 75.2\right), \mathrm{C}$ $8\left(\delta_{\mathrm{C}} 83.8\right), \mathrm{C}-9\left(\delta_{\mathrm{C}} 85.4\right)$ and C-30 $\left(\delta_{\mathrm{C}} 78.0\right)$ confined the location of the orthoester group to $\mathrm{C}-8 / \mathrm{C}-9 / \mathrm{C}-30 .{ }^{13,16)}$

The ROESY correlations (Fig. 2), from H-5 to H-11 and $\mathrm{H}-12$, from $\mathrm{H}-17$ to $\mathrm{H}-12$, from $\mathrm{H}-15$ to $\mathrm{H}-30$, from $\mathrm{H}-3$ to $\mathrm{H}-29 \mathrm{a}$, from $\mathrm{Me}-19$ to $\mathrm{H}-29 \mathrm{~b}$, indicated the basic skeleton of 1 to be the same as that of xyloccensin $\mathrm{O}-\mathrm{V}$ which had been unequivocally been elucidated by X-ray analysis. ${ }^{13)}$ The H-6 proton showed nuclear Overhauser effect (NOE) correlations with $\mathrm{H}-5, \mathrm{H}-11$, and $\mathrm{H}-12$, which suggested the dihedral angle with $\mathrm{H}-5$ was near $90^{\circ}$ and adopted an $\alpha$-orientation. ${ }^{16)}$ Thus, the structure of $\mathbf{1}$ was established as shown.

Tabulalide G (2), white amorphous powder, gave the molecular formula $\mathrm{C}_{39} \mathrm{H}_{46} \mathrm{O}_{18}$ established by HR-ESI-MS ion at $\mathrm{m} / z$ 825.2563 [M+Na ${ }^{+}$(Calcd: $\left.\mathrm{C}_{39} \mathrm{H}_{46} \mathrm{O}_{18} \mathrm{Na}, 825.2576\right)$. The similarity of ${ }^{1} \mathrm{H}$ - and ${ }^{13} \mathrm{C}-\mathrm{NMR}$ spectral data of $\mathbf{2}$ and $\mathbf{1}$ indicated that 2 possessed a phragmalin nucleus with $\Delta^{14,15)}$ $\alpha, \beta$-unsaturated $\delta$-lactone ring (D ring) and an orthoester group at C-8/C-9/C-30 as 1 . A characteristic orthoester carbon signal at $\delta_{\mathrm{C}} 119.9$ showed HMBC correlations with a methyl proton signal at $\delta_{\mathrm{H}} 1.70$, suggesting the orthoester moiety in $\mathbf{2}$ was an orthoacetate group. Three acetyl groups were assignable to $\mathrm{C}-3\left(\delta_{\mathrm{C}} 85.6\right), \mathrm{C}-11\left(\delta_{\mathrm{C}} 67.3\right)$, and $\mathrm{C}-12$ $\left(\delta_{\mathrm{C}} 69.1\right)$ according to their corresponding HMBC correlations, and one isobutyryl group was attached at $\mathrm{C}-2$ on the basis of the chemical shift of $\mathrm{C}-2$ and C-30. ${ }^{13)}$ The nuclear Overhauser effect spectroscopy (NOESY) experiment indicated the relative stereochemistry of $\mathbf{2}$ was to be the same as 1. Thus, the structure of $\mathbf{2}$ was demonstrated as shown.

The absolute stereochemistry of C-17 in $\mathbf{1}$ and $\mathbf{2}$ was determined by $\mathrm{CD}$ exciton chirality method. Two main intramolecular chromophores, the furan ring and the $\Delta^{14,15)}$ $\alpha, \beta$-unsaturated $\delta$-lactone ring, are connected through the chiral center of $\mathrm{C}-17$, which induce the exciton coupling split of its CD spectrum. ${ }^{1)}$ A positive chirality resulting from the exciton coupling at $190\left(\Delta \varepsilon-3.1, \pi \rightarrow \pi^{*}\right.$ transition $)$ and $216 \mathrm{~nm}(\Delta \varepsilon+15.1 \pi \rightarrow \pi *$ transition) observed in CD spectrum in acetonitrile (Fig. 3), which indicated that the transition dipole moments of two chromophores are oriented in a clockwise manner corresponding to the absolute configuration of C-17 as $R .^{1)}$ The CD spectra of $\mathbf{1}$ and $\mathbf{2}$ are also highly consistent in methanol, thus, the absolute configuration of $\mathrm{C}$ 17 in $\mathbf{1}$ and $\mathbf{2}$ was assigned as $R$ unambiguously, which is accordance with xyloccensins $\mathrm{Q}-\mathrm{V}$ isolated from Chinese mangrove Xylocarpus granatum. ${ }^{13,16)}$

Tabulalide $\mathrm{H}$ (3), white amorphous powder, has a molecular formula of $\mathrm{C}_{30} \mathrm{H}_{34} \mathrm{O}_{14}$ as established by its HR-ESI-MS ion at $m / z$ 641.1843 $[\mathrm{M}+\mathrm{Na}]^{+}$(Calcd: $\mathrm{C}_{30} \mathrm{H}_{34} \mathrm{O}_{14} \mathrm{Na}$, 641.1841). The data from $1 \mathrm{D}$ - and $2 \mathrm{D}-\mathrm{NMR}$ studies $\left({ }^{1} \mathrm{H},{ }^{13} \mathrm{C}\right.$, HMBC, HSQC, and NOESY) revealed the presence of characteristic moieties of phragmalins, such as a $\beta$-substituted furanyl ring, characteristic 4,29,1-ring bridge, and an orthoacetate group. The HMBC correlations from two germinal oxygenated methylene signal at $\delta_{\mathrm{H}} 4.44$ and 4.52 to a carbonyl carbon at $\delta_{\mathrm{C}} 172.4(\mathrm{C}-7)$ indicated that methyl-19 have been oxygenated and formed a $\delta$-lactone ring between $\mathrm{C}-7$. The information mentioned above suggested that $\mathbf{3}$ was also a phragmalin-type limonoid orthoester with C-7/C-19 $\delta$-lactone ring. ${ }^{6)}$ The exclusive acetyl was assigned to $\mathrm{C}-12$ according to the HMBC correlation from H-12 $\left(\delta_{\mathrm{H}} 4.54\right)$ to the carbonyl carbon at $\delta_{\mathrm{C}} 169.8$. The proton signals of OH-2 $\left(\delta_{\mathrm{H}}\right.$ $4.00, \mathrm{~s}), \mathrm{OH}-3\left(\delta_{\mathrm{H}} 5.60\right), \mathrm{OH}-11\left(\delta_{\mathrm{H}} 5.54\right), \mathrm{OH}-30\left(\delta_{\mathrm{H}} 4.49\right)$ were distinguished from HSQC and HMBC spectra. On the basis of the analysis above, the orthoacetate moiety was restricted to $\mathrm{C}-1 / \mathrm{C}-8 / \mathrm{C}-9$. Thus, the structure of $\mathbf{3}$ was determined as depicted.

Tabulalides I (4) and J (5) exhibited quasimolecular ions at $\mathrm{m} / \mathrm{z} 683.1944[\mathrm{M}+\mathrm{Na}]^{+}$and $683.1948[\mathrm{M}+\mathrm{Na}]^{+}$in their HR-ESI-MS, respectively, which indicated both compounds have same molecular formula as $\mathrm{C}_{32} \mathrm{H}_{36} \mathrm{O}_{15}$. The closely similarity of the general features of the ${ }^{1} \mathrm{H}$ - and ${ }^{13} \mathrm{C}-\mathrm{NMR}$ data of $\mathbf{3}-\mathbf{5}$ suggested that $\mathbf{4}$ and $\mathbf{5}$ were also phragmalin-type limonoid orthoesters with $\mathrm{C}-7 / \mathrm{C}-19 \delta$-lactone ring. The difference observed was the presence of an additional acetyl signal in NMR spectra of $\mathbf{4}$ and $\mathbf{5}$, which was assigned to C-3 and $\mathrm{C}-11$ according to the key HMBC cross-peaks, respectively. This deduction was also confirmed by the downfield 
shift of H-3 $\left(\Delta \delta_{\mathrm{H}} 1.53\right)$ in 4 and H-11 $\left(\Delta \delta_{\mathrm{H}} 1.19\right)$ in $\mathbf{5}$ when compared with that of $\mathbf{3}$. Thus, the structures of $\mathbf{4}$ and $\mathbf{5}$ were established as the 3-O-acetyl and 11-O-acetyl derivatives of 3, respectively.

Tabulalide $\mathrm{K}$ (6) was isolated as white amorphous powder, and its molecular formula was established to be $\mathrm{C}_{39} \mathrm{H}_{46} \mathrm{O}_{19}$ by its HR-ESI-MS ion at $m / z \quad 841.2509[\mathrm{M}+\mathrm{Na}]^{+}$(Calcd:

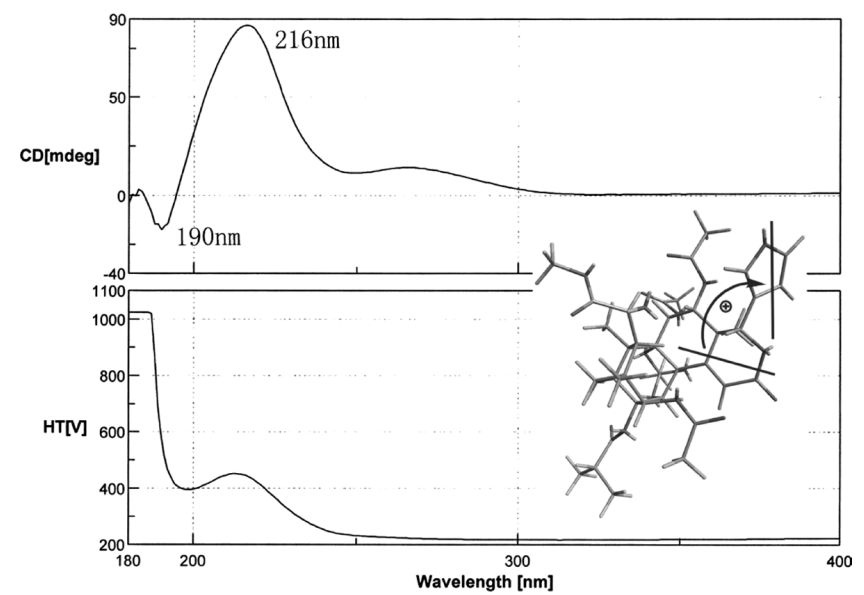

Fig. 3. CD Spectrum of $\mathbf{2}$

Bold lines denote the electric transition dipole of the chromophores.
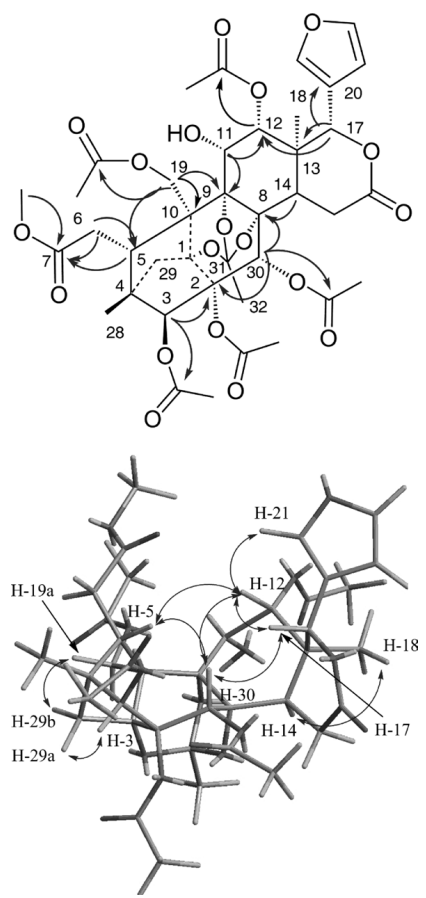

Fig. 4. Selected HMBC and ROESY Correlations of 6

Table 1. ${ }^{1} \mathrm{H}-\mathrm{NMR}$ Data of Compounds $\mathbf{1}-\mathbf{5}$

\begin{tabular}{|c|c|c|c|c|c|}
\hline Position & $\mathbf{1}^{a)}$ & $\mathbf{2}^{a)}$ & $3^{b)}$ & $4^{a)}$ & $5^{a)}$ \\
\hline 3 & $5.11, \mathrm{~s}$ & $5.12, \mathrm{~s}$ & $3.23, \mathrm{~d}(5.4)$ & $4.76, \mathrm{~s}$ & $3.60, \mathrm{~s}$ \\
\hline 5 & $2.37, \mathrm{brs}$ & 2.33, br s & $2.64, \mathrm{~m}$ & $2.81, \mathrm{~m}$ & 2.84 br s \\
\hline $6 a$ & $5.19, \mathrm{~m}^{c)}$ & 5.15 , brs & $2.21, \mathrm{~d}(17.0)$ & $2.64, \mathrm{~m}$ & $2.60, \mathrm{~d}(14.7)$ \\
\hline $6 \mathrm{~b}$ & & & $2.73, \mathrm{dd}(17.0,4.8)$ & $2.80, \mathrm{~m}$ & 2.82, dd $(14.7,4.9)$ \\
\hline 11 & $5.77, \mathrm{~d}(3.9)$ & $5.70, \mathrm{~d}(4.0)$ & 4.32, br s & 4.41 , br s & $5.51, \mathrm{~d}(2.2)$ \\
\hline 12 & $4.89, \mathrm{~d},(3.9)$ & $4.92, \mathrm{~d}(4.0)$ & 4.54 , br s & 4.66 , brs & $4.72, \mathrm{~d}(2.2)$ \\
\hline 14 & & & $2.65, \mathrm{~m}$ & $2.71, \mathrm{~m}$ & $2.54, \mathrm{~d}(9.8)$ \\
\hline $15 \mathrm{a}$ & $6.47, \mathrm{~s}$ & $6.65, \mathrm{~s}$ & 2.65, brd (18.6) & $2.70, \mathrm{~m}$ & $2.70, \mathrm{dd}(19.0,9.8)$ \\
\hline $15 \mathrm{~b}$ & & & $3.08, \mathrm{~d}(18.6)$ & $3.28, \mathrm{~m}$ & 3.25, brd $(19.0)$ \\
\hline 17 & $5.84, \mathrm{~s}$ & $5.83, \mathrm{~s}$ & 5.45 & $5.47, \mathrm{~s}$ & $5.54, \mathrm{~s}$ \\
\hline 18 & $1.69, \mathrm{~s}, 3 \mathrm{H}$ & $1.71, \mathrm{~s}, 3 \mathrm{H}$ & $1.35, \mathrm{~s}, 3 \mathrm{H}$ & $1.48, \mathrm{~s}, 3 \mathrm{H}$ & $1.41, \mathrm{~s}, 3 \mathrm{H}$ \\
\hline $19 \mathrm{a}$ & $1.60, \mathrm{~s}, 3 \mathrm{H}$ & $1.60, \mathrm{~s}, 3 \mathrm{H}$ & $4.44, \mathrm{~d}(13.8)$ & $4.28, \mathrm{~d}(11.7)$ & $4.62, \mathrm{brs}$ \\
\hline $19 b$ & & & $4.52, \mathrm{~d}(13.8)$ & $4.77, \mathrm{~d}(11.7)$ & 4.62 , br s \\
\hline 21 & 7.40, br s & 7.41, br s & 7.70, br s & 7.42, br s & 7.38, br s \\
\hline 22 & 6.54 , br s & 6.54, brd $(1.0)$ & 6.44 , br s & 6.43, brs & 6.39, brs \\
\hline 23 & $7.40, \mathrm{brs}$ & 7.40, t-like $(1.5)$ & 7.47 , br s & 7.35, brs & 7.35, br s \\
\hline 28 & $0.93, \mathrm{~s}, 3 \mathrm{H}$ & $0.90, \mathrm{~s}, 3 \mathrm{H}$ & $0.83, \mathrm{~s}, 3 \mathrm{H}$ & $1.09, \mathrm{~s}, 3 \mathrm{H}$ & $1.10, \mathrm{~s}, 3 \mathrm{H}$ \\
\hline $29 a$ & $1.75, \mathrm{~d}(11.0)$ & $1.68, \mathrm{~d}(11.0)$ & $1.52, \mathrm{~d}(10.2)$ & $1.84, \mathrm{~d}(11.3)$ & $1.64, \mathrm{~d}(11.0)$ \\
\hline $29 b$ & $2.29, \mathrm{~d}(11.0)$ & $2.41, \mathrm{~d}(11.0)$ & $1.88, \mathrm{~d}(10.2)$ & $2.36, \mathrm{~d}(11.3)$ & $2.26, \mathrm{~d}(11.0)$ \\
\hline 30 & $4.51, \mathrm{~s}$ & $5.36, \mathrm{~s}$ & 4.47, d (5.4) & $4.35, \mathrm{~s}$ & $4.58, \mathrm{~s}$ \\
\hline 32 & $2.20, \mathrm{~m}(7.0)^{c}$ & $1.70, \mathrm{~s}, 3 \mathrm{H}$ & $1.62, \mathrm{~s}, 3 \mathrm{H}$ & $1.77, \mathrm{~s}, 3 \mathrm{H}$ & $1.67, \mathrm{~s}, 3 \mathrm{H}$ \\
\hline 33 & $1.10, \mathrm{t}(7.0), 3 \mathrm{H}$ & & & & \\
\hline 34 & $1.10, \mathrm{t}(7.0), 3 \mathrm{H}$ & & & & \\
\hline $\mathrm{OH}-1$ & 3.28, br s & & & & \\
\hline $\mathrm{OH}-2$ & & & $4.00, \mathrm{~s}$ & & \\
\hline $\mathrm{OH}-3$ & & & $5.60, \mathrm{~d}(5.4)$ & & \\
\hline $\mathrm{OH}-11$ & & & $5.54, \mathrm{~d}(4.2)$ & & \\
\hline $\mathrm{OH}-30$ & & & $4.59, \mathrm{~d}(5.4)$ & & \\
\hline $\mathrm{OCH}_{3}-7$ & $3.83, \mathrm{~s}, 3 \mathrm{H}$ & $3.82, \mathrm{~s}, 3 \mathrm{H}$ & & & \\
\hline OCOCH- & & $2.67, \mathrm{~m}$ & & & \\
\hline$\left(\mathrm{CH}_{3}\right)_{2}-2$ & & $1.19, \mathrm{~d}(7.0)$ & & & \\
\hline & & $1.21, \mathrm{~d}(7.0)$ & & & \\
\hline OAc-3 & $2.04, \mathrm{~s}, 3 \mathrm{H}$ & $2.08, \mathrm{~s}, 3 \mathrm{H}$ & & $2.14, \mathrm{~s}, 3 \mathrm{H}$ & \\
\hline OAc-11 & $2.05, \mathrm{~s}, 3 \mathrm{H}$ & $2.07, \mathrm{~s}, 3 \mathrm{H}$ & & & $2.12, \mathrm{~s}, 3 \mathrm{H}$ \\
\hline OAc-12 & $1.48, \mathrm{~s}, 3 \mathrm{H}$ & $1.49, \mathrm{~s}, 3 \mathrm{H}$ & $1.65, \mathrm{~s}, 3 \mathrm{H}$ & $1.77, \mathrm{~s}, 3 \mathrm{H}$ & $1.69, \mathrm{~s}, 3 \mathrm{H}$ \\
\hline
\end{tabular}

a) Recorded at $500 \mathrm{MHz}\left({ }^{1} \mathrm{H}\right)$ and $125 \mathrm{MHz}\left({ }^{13} \mathrm{C}\right)$ in $\mathrm{CDCl}_{3}$. b) Recorded at $600 \mathrm{MHz}\left({ }^{1} \mathrm{H}\right)$ and $150 \mathrm{MHz}\left({ }^{13} \mathrm{C}\right)$ in DMSO- $d_{6}$. c) Signal pattern unclear due to overlapping. 
$\mathrm{C}_{39} \mathrm{H}_{46} \mathrm{O}_{19} \mathrm{Na}$, 841.2526). The data from decouplings and subsequent $1 \mathrm{D}$ - and $2 \mathrm{D}-\mathrm{NMR}$ studies $\left({ }^{1} \mathrm{H},{ }^{13} \mathrm{C}, \mathrm{HMBC}\right.$, HSQC, and NOESY) indicated that compound $\mathbf{6}$ was a phragmalin-type limonoid orthoerester like tabulalide $\mathrm{D},{ }^{6}$ which was confirmed by the presences of an orthoacetate group, a $\beta$-substituted furanyl ring, oxygenated C-19 methylene signals, the characteristic proton signals of 4,29,1-ring bridge. Four acetyls was attached to C-3, C-12, C-19, and C30 based on the HMBC correlations (Fig. 4), and the last one was assigned to $\mathrm{C}-2$ on the basis of the downfield chemical shift of C-2 at $\delta_{\mathrm{C}} 85.2 .^{9,10)}$ The chemical shift of H-11 at $\delta_{\mathrm{H}}$ 4.83 matched well with that of tabulalide $\mathrm{C}$, suggesting a free hydroxyl at $\mathrm{C}-11$ of $\mathbf{6}$, which was also confirmed by the absent HMBC correlation between H-11 and carbonyl carbon. ${ }^{6}$ Thus, the only possible position of the orthoacetate group was at C-1/C-8/C-9. The relative configuration of 6 was determined to be the same as tabulalide $\mathrm{D}^{6}$ ) by its key NOE correlations, from $\mathrm{H}-12$ to $\mathrm{H}-11, \mathrm{H}-17, \mathrm{H}-30$, and $\mathrm{H}-5$, from H-17 to H-30, from H-5 to H-30, from H-3 to H-29a, from $\mathrm{H}-29 \mathrm{~b}$ to $\mathrm{H}-19 \mathrm{a}$, and from Me-18 to H-14. Thus, the structure of $\mathbf{6}$ was demonstrated as 2,30-O-diacetylated tabulalide D.

Tabulalide L (7), white amorphous powder, gave the same molecular formula of $\mathrm{C}_{39} \mathrm{H}_{46} \mathrm{O}_{19}$ as $\mathbf{6}$, determined by the HRESI-MS ion at $\mathrm{m} / z$ 841.2529 $[\mathrm{M}+\mathrm{Na}]^{+}$. The similarity of ${ }^{1} \mathrm{H}$ - and ${ }^{13} \mathrm{C}$-NMR spectroscopic data of 7 and $\mathbf{6}$ indicated that both natural products possessed the same skeleton. When comparied with $\mathbf{6}$, the chemical shift of $\mathrm{C}-2$ upfield shifted from $\delta_{\mathrm{C}} 85.2$ to 79.3 and H-11 downfield shifted from $\delta_{\mathrm{H}} 4.83$ to 6.10 . These changes indicated that the acetyl at C2 in 6 transfered to $\mathrm{C}-11$ in 7, which was confirmed by HMBC correlation from $\mathrm{H}-11$ to a carbonyl carbon at $\delta_{\mathrm{C}}$ 170.1. Thus, the structure of 7 was demonstrated to be 11,30 $O$-diacetylated tabulalide D.

Tabulalide $\mathrm{M}(\mathbf{8})$, white amorphous powder, gave a molecular formula of $\mathrm{C}_{35} \mathrm{H}_{42} \mathrm{O}_{17}$ determined by its HR-ESI-MS ion at $\mathrm{m} / \mathrm{z} 757.2324[\mathrm{M}+\mathrm{Na}]^{+}$. The MS and data from decouplings and subsequent 1D- and 2D-NMR studies $\left({ }^{1} \mathrm{H},{ }^{13} \mathrm{C}\right.$, HMBC, HSQC, and ROESY) indicated that compound $\mathbf{8}$ was a bideacetyl derivative of 7 . Based on the coherent HMBC correlations, three acetyls were located at C-11, C-12, and C19 , respectively. Thus, compound $\mathbf{8}$ was demonstrated as 3,30-O-dideacetyed 7, and its relative configuration was determined as the same as 7 by ROESY experiment.

The molecular formula of $\mathbf{9}$, tabulalide $\mathrm{O}$, was determined to be $\mathrm{C}_{36} \mathrm{H}_{44} \mathrm{O}_{17}$ by its HR-ESI-MS ion at $\mathrm{m} / \mathrm{z} 771.2466$ $[\mathrm{M}+\mathrm{Na}]^{+}$. The general feature of ${ }^{1} \mathrm{H}-$ and ${ }^{13} \mathrm{C}-\mathrm{NMR}$ spectroscopic data indicated that 9 was also a phragmalin limonoid orthothester as tabulalide $\mathrm{D},{ }^{6}$ with the additional signals corresponding to a propionyl group $\left[\delta_{\mathrm{H}} 2.34(\mathrm{q}, J=7.6 \mathrm{~Hz}, 2 \mathrm{H})\right.$, $\left.1.12(\mathrm{t}, J=7.6 \mathrm{~Hz}, 3 \mathrm{H}) ; \delta_{\mathrm{C}} 173.3,27.7,8.7\right]$. The key HMBC correlations relvealed that two acetyls and one propionyl attached at C-3, C-12, and C-19, respectively. Thus, the structure of 9 was demonstrated as shown, which is 19-O-propionyl derivate of tabulalide $\mathrm{D}$.

Compounds 10-12 were identified to be known compounds, tabulalides $\mathrm{C}$ and $\mathrm{D}$ and tabularisin $\mathrm{N}$, by comparison of the NMR and MS data with the published values. ${ }^{6,9)}$

Compounds 2-12 were tested for cytotoxic activity against five human cancer cell lines, MCF-7 (human breast cancer), Hela (human cervical cancer), SGC-7901 and BGC-
Table 2. ${ }^{13} \mathrm{C}$-NMR Data of Compounds $\mathbf{1}-\mathbf{5}$

\begin{tabular}{|c|c|c|c|c|c|}
\hline Position & $\mathbf{1}^{a)}$ & $2^{a)}$ & $3^{b)}$ & $4^{a)}$ & $5^{a)}$ \\
\hline 1 & 84.6 & 84.7 & 83.8 & 83.9 & 84.3 \\
\hline 2 & 75.2 & 83.0 & 77.7 & 77.7 & 78.3 \\
\hline 3 & 86.0 & 85.6 & 83.3 & 83.2 & 83.0 \\
\hline 4 & 44.1 & 44.3 & 45.3 & 44.8 & 44.9 \\
\hline 5 & 45.9 & 48.5 & 32.3 & 35.2 & 33.5 \\
\hline 6 & 70.9 & 70.9 & 30.9 & 31.0 & 31.0 \\
\hline 7 & 174.5 & 174.5 & 172.4 & 171.3 & 172.4 \\
\hline 8 & 83.8 & 83.8 & 85.5 & 86.4 & 86.2 \\
\hline 9 & 85.4 & 85.2 & 85.1 & 85.1 & 84.7 \\
\hline 10 & 48.2 & 48.5 & 44.2 & 45.6 & 46.3 \\
\hline 11 & 67.3 & 67.3 & 69.2 & 70.4 & 69.6 \\
\hline 12 & 69.1 & 69.1 & 71.1 & 71.6 & 70.0 \\
\hline 13 & 42.0 & 42.1 & 37.6 & 38.4 & 38.1 \\
\hline 14 & 151.8 & 151.3 & 40.9 & 41.6 & 42.4 \\
\hline 15 & 123.6 & 124.1 & 26.8 & 27.0 & 27.3 \\
\hline 16 & 163.3 & 163.2 & 169.9 & 170.1 & 171.2 \\
\hline 17 & 78.9 & 18.9 & 76.1 & 76.6 & 77.0 \\
\hline 18 & 15.1 & 15.8 & 15.5 & 15.8 & 15.9 \\
\hline 19 & 17.6 & 17.5 & 68.2 & 68.1 & 68.0 \\
\hline 20 & 121.0 & 121.0 & 121.1 & 121.3 & 120.7 \\
\hline 21 & 142.0 & 142.0 & 140.7 & 140.4 & 141.1 \\
\hline 22 & 110.2 & 110.2 & 109.9 & 110.0 & 109.9 \\
\hline 23 & 143.1 & 143.1 & 143.6 & 143.4 & 143.2 \\
\hline 28 & 15.3 & 15.2 & 14.1 & 13.9 & 14.0 \\
\hline 29 & 40.3 & 41.6 & 38.2 & 38.7 & 38.5 \\
\hline 30 & 78.0 & 74.3 & 67.6 & 68.7 & 68.0 \\
\hline 31 & 123.0 & 119.9 & 118.9 & 120.3 & 120.2 \\
\hline 32 & 29.5 & 15.2 & 20.9 & 21.1 & 21.1 \\
\hline 33 & 17.1 & & & & \\
\hline 34 & 17.2 & & & & \\
\hline \multirow[t]{2}{*}{$\mathrm{OCH}_{3}-7$} & 53.1 & 53.1 & & & \\
\hline & & 176.5 & & & \\
\hline OCOCH- & & 34.4 & & & \\
\hline \multirow[t]{2}{*}{$\left(\mathrm{CH}_{3}\right)_{2}-2$} & & 18.7 & & & \\
\hline & & 18.7 & & & \\
\hline \multirow[t]{2}{*}{ OAc-3 } & 169.6 & 168.8 & & 169.7 & \\
\hline & 21.7 & 20.7 & & 20.9 & \\
\hline \multirow[t]{2}{*}{ OAc-11 } & 170.0 & 169.6 & & & 169.4 \\
\hline & 20.9 & 21.7 & & & 20.6 \\
\hline \multirow[t]{2}{*}{ OAc-12 } & 170.3 & 170.3 & 170.4 & 171.2 & 170.4 \\
\hline & 19.5 & 19.5 & 19.9 & 20.3 & 19.9 \\
\hline
\end{tabular}

a) Recorded at $500 \mathrm{MHz}\left({ }^{1} \mathrm{H}\right)$ and $125 \mathrm{MHz}\left({ }^{13} \mathrm{C}\right)$ in $\mathrm{CDCl}_{3}$. b) Recorded at $600 \mathrm{MHz}\left({ }^{1} \mathrm{H}\right)$ and $150 \mathrm{MHz}\left({ }^{13} \mathrm{C}\right)$ in DMSO- $d_{6}$.

823 (human gastric cancer), HepG2 (human liver cancer), by a 3-(4,5-dimethylthiazol-2-yl)-2,5-diphenyltetrazolium bromide (MTT) assay. The preliminary result showed that compound 2 exhibited moderate cytotoxic activity against MCF7 with $\mathrm{IC}_{50}$ value of $20.4 \mu \mathrm{mol} / 1$ and weak cytotoxic activity against SGC-7901 with $\mathrm{IC}_{50}$ value of $63.4 \mu \mathrm{mol} / 1$. Compounds $\mathbf{5}, \mathbf{6}$, and 12 exhibited weak cytotoxic activity against HepG2 with $\mathrm{IC}_{50}$ value of $82.2,91.6,87.2 \mu \mathrm{mol} / 1$, respectively. The other isolates were noncytotoxic $\left(\mathrm{IC}_{50}>100\right.$ $\mu \mathrm{mol} / \mathrm{l})$. Taxol was used as positive control substance with $\mathrm{IC}_{50}$ value of $0.0031,0.014,0.022,0.085,0.014 \mu \mathrm{mol} / 1$ against these five human cancer cell lines, respectively.

\section{Experimental}

General Experimental Procedures Optical rotations were measured with a JASCO P-1020 polarimeter, CD spectra were obtained on a JASCO 810 spectropolarimeter. IR ( $\mathrm{KBr}$ disks) spectra were recorded by Bruker Tensor 27 spectrometer. NMR spectra were recorded on Bruker ACF-500 and $600 \mathrm{NMR}$ instrument, $\left({ }^{1} \mathrm{H}\right.$ : 500 or $600 \mathrm{MHz},{ }^{13} \mathrm{C}: 125$ or $\left.150 \mathrm{MHz}\right)$. Mass spectra were obtained on a MS Agilent 1100 Series LC/MSD Trap mass spectrometer (ESI-MS) and a Micro Q-TOF MS (HR-ESI-MS), re- 
spectively. All solvents used were of analytical grade (Jiangsu Hanbang Sci. \& Tech. Co., Ltd., China). Silica gel (Qingdao Haiyang Chemical Co., Ltd., China), Sephadex LH-20 (Pharmacia, U.S.A.), and RP-C ${ }_{18}(40-63 \mu \mathrm{m}$, FuJi, Japan) were used for column chromatography. Preparative HPLC was carried out using Agilent 1100 Series with Shim-park RP-C ${ }_{18}$ column $(20 \times 200 \mathrm{~mm})$ and 1100 Series Multiple Wavelength detector.

Plant Material The air-dried stem barks of $C$. tabularis var. velutina were collected from Xishuangbanna, Yunnan Province, China, and were authenticated by Professor Mian Zhang of the Research Department of Pharmacognosy, China Pharmaceutical University. A voucher specimen (No. 2006-MML) has been deposited in the Department of Natural Medicinal Chemistry, China Pharmaceutical University.

Extraction and Isolation The air-dried stem barks $(10 \mathrm{~kg})$ were extracted with refluxing 95\% ethanol three times. The EtOH extract was concentrated under reduced pressure $(2000 \mathrm{~g})$ and then extracted with $\mathrm{CHCl}_{3}$ to give the chloroform extract $(300 \mathrm{~g})$. The oily chloroform extract was dis- solved in $2150 \% \mathrm{MeOH}$ and $\mathrm{H}_{2} \mathrm{O}$ and then extracted with petroleum ether (PE). After removal of the fatty components, $210 \mathrm{~g}$ of extraction were obtained, which was subjected to a silica gel column eluted with $\mathrm{CHCl}_{3} / \mathrm{MeOH}$ in gradient $(1: 0$ to $1: 2)$ to afford eight fractions (Fr. A-H) according to TLC monitor. Fr. C (22 g) was chromatographed on a column of silica gel eluted successively with a gradient of PE/EtOAc $(4: 1$ to $1: 2)$ to give eight sub-fractions (Fr. C1-C8). Fr. C2 was chromatographed on a column of reversed-phase $\mathrm{C}_{18}$ silica gel eluted with $\mathrm{MeOH} / \mathrm{H}_{2} \mathrm{O}(5: 5$ to $7: 3)$ to give a mixture contained 1 , then the mixture was purified by $\mathrm{CH}_{3} \mathrm{CN}-\mathrm{H}_{2} \mathrm{O}(50: 50$, $10 \mathrm{ml} / \mathrm{min})$ as the mobile phase to give $\mathbf{1}(6 \mathrm{mg})$. Fr. C3 was chromatographed on a column of reversed-phase $\mathrm{C}_{18}$ silica gel eluted with $\mathrm{MeOH} / \mathrm{H}_{2} \mathrm{O}(1: 1$ to $3: 1)$ to give four sub-fractions (Fr. C3a-C3d), then Fr. C32 was separated by preparative HPLC using $\mathrm{MeOH} / \mathrm{H}_{2} \mathrm{O}$ (68:32, $10 \mathrm{ml} / \mathrm{min})$ as the mobile phase to give $2(20 \mathrm{mg})$. Fr. C7 was chromatographed on a column of reversed-phase $\mathrm{C}_{18}$ silica gel eluted with $\mathrm{MeOH}-\mathrm{H}_{2} \mathrm{O}(5: 5$ to $7: 3)$ to give three sub-fractions (Fr. C7a-C7e). Fr.

Table 3. ${ }^{1} \mathrm{H}$ - and ${ }^{13} \mathrm{C}$-NMR Data of $\mathbf{6}-9$ (in $\mathrm{CDCl}_{3}$ )

\begin{tabular}{|c|c|c|c|c|c|c|c|c|}
\hline \multirow{2}{*}{ Position } & \multicolumn{2}{|l|}{$6^{a)}$} & \multicolumn{2}{|l|}{$7^{b)}$} & \multicolumn{2}{|l|}{$\mathbf{8}^{a)}$} & \multicolumn{2}{|l|}{$\mathbf{9}^{a)}$} \\
\hline & $\delta_{\mathrm{H}}(J$ in $\mathrm{Hz})$ & $\delta_{\mathrm{C}}$ & $\delta_{\mathrm{H}}(J$ in $\mathrm{Hz})$ & $\delta_{\mathrm{C}}$ & $\delta_{\mathrm{H}}(J$ in $\mathrm{Hz})$ & $\delta_{\mathrm{C}}$ & $\delta_{\mathrm{H}}(J$ in $\mathrm{Hz})$ & $\delta_{\mathrm{C}}$ \\
\hline 1 & & 85.0 & & 85.0 & & 84.0 & & 83.7 \\
\hline 2 & & 85.2 & & 79.3 & & 78.4 & & 77.7 \\
\hline 3 & $5.15, \mathrm{~s}$ & 80.7 & $4.70, \mathrm{~s}$ & 82.7 & $3.60, \mathrm{~s}$ & 83.6 & $4.74, \mathrm{~s}$ & 82.6 \\
\hline 4 & & 46.1 & & 45.4 & & 45.8 & & 45.5 \\
\hline 5 & 3.12, br d (11.1) & 34.8 & 3.14, br d $(10.8)$ & 35.6 & 3.13, brd (11.2) & 35.2 & 3.23, br d $(11.0)$ & 36.4 \\
\hline $6 a$ & 2.48, dd $(11.1,17.6)$ & 32.8 & 2.50, dd $(17.4,10.8)$ & 32.6 & 2.48, dd $(17.4,11.2)$ & 32.5 & 2.48, dd $(17.5,11.0)$ & 32.8 \\
\hline $6 \mathrm{~b}$ & 2.68, brd $(17.6)$ & & 2.90, brd $(17.4)$ & & 2.97, brd $(17.4)$ & & 2.75, dd $(17.5,3.0)$ & \\
\hline 7 & & 171.8 & & 172.3 & & 173.8 & & 172.0 \\
\hline 8 & & 85.8 & & 86.0 & & 86.8 & & 86.9 \\
\hline 9 & & 85.5 & & 85.1 & & 84.3 & & 84.8 \\
\hline 10 & & 47.5 & & 47.1 & & 47.2 & & 47.2 \\
\hline 11 & $4.83, \mathrm{~d}(2.3)$ & 70.7 & 6.10 , brs & 69.2 & $6.11, \mathrm{~d}(2.1)$ & 69.5 & $4.92, \mathrm{~d}(2.3)$ & 70.5 \\
\hline 12 & $4.51, \mathrm{~d}(2.3)$ & 71.8 & 4.56, br s & 70.4 & $4.60, \mathrm{t}(2.1)$ & 70.6 & $4.55, \mathrm{t}(3.7)$ & 71.7 \\
\hline 13 & & 37.7 & & 37.5 & & 37.7 & & 37.9 \\
\hline 14 & 2.80, br d $(10.5)$ & 42.7 & $2.70, \mathrm{~m}^{c)}$ & 42.7 & 2.63, br d (9.9) & 42.3 & 2.78, brd $(10.1)$ & 41.5 \\
\hline $15 \mathrm{a}$ & $2.76, \mathrm{dd}(10.5,16.9)$ & 26.6 & $2.81, \mathrm{~m}^{c)}$ & 27.0 & 2.71, dd $(19.0,9.9)$ & 27.6 & 2.69, dd $(19.1,10.1)$ & 7.4 \\
\hline $15 \mathrm{~b}$ & 3.31, dd $(2.1,16.9)$ & & 3.28, br d $(18.6)$ & & 3.31, br d $(19.0)$ & & 3.27, brd $(19.1)$ & \\
\hline 16 & & 169.7 & & 169.6 & & 170.7 & & 170.4 \\
\hline 17 & $5.51, \mathrm{~s}$ & 76.9 & $5.55, \mathrm{~s}$ & 76.9 & $5.67, \mathrm{~s}$ & 77.0 & $5.58, \mathrm{~s}$ & 76.8 \\
\hline 18 & $1.45, \mathrm{~s}, 3 \mathrm{H}$ & 15.6 & $1.33, \mathrm{~s}, 3 \mathrm{H}$ & 15.6 & $1.30, \mathrm{~s}, 3 \mathrm{H}$ & 15.8 & $1.43, \mathrm{~s}, 3 \mathrm{H}$ & 15.7 \\
\hline $19 \mathrm{a}$ & $4.19, \mathrm{~d}(11.6)$ & 66.5 & $4.29, \mathrm{~d}(12.0)$ & 66.1 & $4.29, \mathrm{~d}(12.0)$ & 66.2 & $4.19, \mathrm{~d}(11.6)$ & 66.1 \\
\hline $19 b$ & $4.56, \mathrm{~d}(11.6)$ & & $4.48, \mathrm{~d}(12.0)$ & & $4.51, \mathrm{~d}(12.0)$ & & $4.59, \mathrm{~d}(11.6)$ & \\
\hline 20 & & 121.0 & & 120.7 & & 121.0 & & 121.5 \\
\hline 21 & 7.45, brs & 141.2 & 7.45, brs & 141.0 & 7.42, brs & 140.9 & 7.41, br s & 140.4 \\
\hline 22 & $6.45, \mathrm{~d}(1.2)$ & 110.0 & 6.40, brs & 109.6 & 6.37, brs & 109.8 & 6.45, brs & 109.8 \\
\hline 23 & 7.39, t-like $(1.7)$ & 143.2 & 7.39, br s & 143.2 & 7.35, br s & 142.8 & 7.41 , br s & 143.1 \\
\hline 28 & $0.93, \mathrm{~s}, 3 \mathrm{H}$ & 14.2 & $0.93, \mathrm{~s}, 3 \mathrm{H}$ & 14.1 & $1.01, \mathrm{~s}, 3 \mathrm{H}$ & 14.0 & $0.98, \mathrm{~s}, 3 \mathrm{H}$ & 14.1 \\
\hline $29 a$ & $1.74, \mathrm{~d}(11.8)$ & 39.8 & $1.81, \mathrm{~d}(10.8)$ & 39.1 & $1.67, \mathrm{~d}(11.3)$ & 39.6 & $1.82, \mathrm{~d}(11.6)$ & 39.3 \\
\hline $29 b$ & $1.84, \mathrm{~d}(11.8)$ & & $1.91, \mathrm{~d}(10.8)$ & & $1.88, \mathrm{~d}(11.3)$ & & $1.85, \mathrm{~d}(11.6)$ & \\
\hline 30 & $6.38, \mathrm{~s}$ & 68.4 & $6.06, \mathrm{~s}$ & 70.1 & $4.85, \mathrm{~s}$ & 68.1 & $4.67, \mathrm{~s}$ & 68.4 \\
\hline 31 & & 120.2 & & 120.1 & & 120.2 & & 120.3 \\
\hline 32 & $1.76, \mathrm{~s}, 3 \mathrm{H}$ & 21.0 & $1.73, \mathrm{~s}, 3 \mathrm{H}$ & 21.0 & $1.68, \mathrm{~s}, 3 \mathrm{H}$ & 21.1 & $1.74, \mathrm{~s}, 3 \mathrm{H}$ & 21.1 \\
\hline OMe-7 & $3.72, \mathrm{~s}, 3 \mathrm{H}$ & 51.9 & $3.73, \mathrm{~s}, 3 \mathrm{H}$ & 51.9 & $3.75, \mathrm{~s}, 3 \mathrm{H}$ & 52.1 & $3.73, \mathrm{~s}, 3 \mathrm{H}$ & 51.9 \\
\hline \multirow[t]{2}{*}{ OAc-2 } & & 170.1 & & & & & & \\
\hline & $2.15, \mathrm{~s}, 3 \mathrm{H}$ & 21.6 & & & & & & \\
\hline \multirow[t]{2}{*}{ OAc-3 } & & 170.2 & & 171.0 & & & & 170.2 \\
\hline & $2.36, \mathrm{~s}, 3 \mathrm{H}$ & 21.1 & $2.30, \mathrm{~s}, 3 \mathrm{H}$ & 21.4 & & & $2.19, \mathrm{~s}, 3 \mathrm{H}$ & 20.9 \\
\hline \multirow[t]{2}{*}{ OAc-11 } & & & & 169.1 & & 169.3 & & \\
\hline & & & $2.11, \mathrm{~s}, 3 \mathrm{H}$ & 21.0 & $2.10, \mathrm{~s}, 3 \mathrm{H}$ & 20.9 & & \\
\hline \multirow[t]{2}{*}{ OAc-12 } & & 169.8 & & 169.2 & & 169.5 & & 169.8 \\
\hline & $1.66, \mathrm{~s}, 3 \mathrm{H}$ & 20.1 & $1.61, \mathrm{~s}, 3 \mathrm{H}$ & 19.9 & $1.62, \mathrm{~s}, 3 \mathrm{H}$ & 20.0 & $1.68, \mathrm{~s}, 3 \mathrm{H}$ & 20.2 \\
\hline \multirow[t]{3}{*}{ OAc-19 } & & 169.9 & & 170.9 & & 171.0 & & 170.2 \\
\hline & $2.08, \mathrm{~s}, 3 \mathrm{H}$ & 21.1 & $2.03, \mathrm{~s}, 3 \mathrm{H}$ & 21.1 & $2.03, \mathrm{~s}, 3 \mathrm{H}$ & 21.1 & $2.06, \mathrm{~s}, 3 \mathrm{H}$ & 21.2 \\
\hline & & & & & & & & 173.3 \\
\hline $\mathrm{OCOCH}_{2}-$ & & & & & & & $2.34, \mathrm{q}(7.6)$ & 27.7 \\
\hline CH3-19 & & & & & & & $1.12, \mathrm{t}(7.6)$ & 8.7 \\
\hline \multirow[t]{2}{*}{ OAc-30 } & & 168.3 & & 168.6 & & & & \\
\hline & $1.94, \mathrm{~s}, 3 \mathrm{H}$ & 21.5 & $2.10, \mathrm{~s}, 3 \mathrm{H}$ & 21.3 & & & & \\
\hline
\end{tabular}


C7b was separated by preparative HPLC using $\mathrm{CH}_{3} \mathrm{OH} / \mathrm{H}_{2} \mathrm{O}(60: 40$, $10 \mathrm{ml} / \mathrm{min}$ ) as the mobile phase to give $7(5 \mathrm{mg})$. Fr. C8 was chromatographed on a column of reversed-phase $\mathrm{C}_{18}$ silica gel eluted with $\mathrm{MeOH}-\mathrm{H}_{2} \mathrm{O}(5: 5$ to $7: 3)$ to give three sub-fractions (Fr. C8a-C8f). Fr. $\mathrm{C} 8 \mathrm{~b}$ was separated by preparative HPLC using $\mathrm{CH}_{3} \mathrm{OH}-\mathrm{H}_{2} \mathrm{O}(55: 45$, $10 \mathrm{ml} / \mathrm{min})$ as the mobile phase to give $6(30 \mathrm{mg})$. Fr. D $(30 \mathrm{~g})$ was chromatographed on a column of silica gel eluted successively with a gradient of petroleum ether-EtOAc $(5: 2$ to $1: 2)$ to give seven sub-fractions (Fr. D1D7). Fr. D3 was chromatographed on a column of reversed-phase $\mathrm{C}_{18}$ silica gel eluted with $\mathrm{MeOH}-\mathrm{H}_{2} \mathrm{O}$ (5:5 to $7: 3$ ), to give four sub-fractions ( $\mathrm{Fr}$. D3a-D3d). Fr. D3b was separated by preparative HPLC using $\mathrm{CH}_{3} \mathrm{CN}-\mathrm{H}_{2} \mathrm{O}(42: 58,10 \mathrm{ml} / \mathrm{min})$ as the mobile phase, to give $9(6 \mathrm{mg})$. Fr. D4 was chromatographed on a column of reversed-phase $\mathrm{C}_{18}$ silica gel eluted with $\mathrm{MeOH}-\mathrm{H}_{2} \mathrm{O}(5: 5$ to $7: 3)$, to give three sub-fractions (Fr. D4aD4c), and obtained $11(40 \mathrm{mg}$ ) and $12(30 \mathrm{mg})$. Fr. D5 was chromatographed on a column of reversed-phase $\mathrm{C}_{18}$ silica gel eluted with $\mathrm{MeOH}-\mathrm{H}_{2} \mathrm{O}(5: 5$ to $7: 3$ ) to give four sub-fractions (Fr. D5a-D5d). Fr. D5b was purified by preparative HPLC using $\mathrm{CH}_{3} \mathrm{CN}-\mathrm{H}_{2} \mathrm{O}(45: 55,10 \mathrm{ml} / \mathrm{min})$ as the mobile phase, to give $8(18 \mathrm{mg})$. Fr. E (20 g) was chromatographed on a column of reversed-phase $\mathrm{C}_{18}$ silica gel eluted with $\mathrm{MeOH}-\mathrm{H}_{2} \mathrm{O}$ (4:6 to $\left.7: 3\right)$ to give six sub-fractions (Fr. E1-E6), and obtained $10(10 \mathrm{mg})$ Fr. E2 was chromatographed on a column of reversed-phase $\mathrm{C}_{18}$ silica gel eluted with $\mathrm{MeOH}-\mathrm{H}_{2} \mathrm{O}(4: 6$ to $7: 3)$ to give a mixture contained 4, then the mixture was purified by $\mathrm{CH}_{3} \mathrm{CN}-\mathrm{H}_{2} \mathrm{O}(50: 50,10 \mathrm{ml} / \mathrm{min})$ as the mobile phase to give $4(8 \mathrm{mg})$. Fr. E5b was separated by preparative HPLC using $\mathrm{CH}_{3} \mathrm{CN}$ / $\mathrm{H}_{2} \mathrm{O}(40: 60,10 \mathrm{ml} / \mathrm{min})$ as the mobile phase to give $\mathbf{5}(15 \mathrm{mg})$. Fr. F $(20 \mathrm{~g})$ was chromatographed on a column of reversed-phase $\mathrm{C}_{18}$ silica gel eluted with $\mathrm{MeOH}-\mathrm{H}_{2} \mathrm{O}(4: 6$ to $7: 3)$ to give five sub-fractions (Fr. F1-F5). Fr. F2 was chromatographed on a column of reversed-phase $\mathrm{C}_{18}$ silica gel eluted with $\mathrm{MeOH}-\mathrm{H}_{2} \mathrm{O}$ (4:6 to $7: 3$ ) to give four sub-fractions (Fr. F2a-F2d), then Fr. F2a was purified by $\mathrm{CH}_{3} \mathrm{CN}-\mathrm{H}_{2} \mathrm{O}(50: 50,10 \mathrm{ml} / \mathrm{min})$ as the mobile phase to give $3(10 \mathrm{mg})$

Tabulalide F (1): White amorphous powder; $[\alpha]_{\mathrm{D}}^{25}+51.3(c=0.13$, $\left.\mathrm{CH}_{3} \mathrm{OH}\right) ; \mathrm{CD}\left(\mathrm{CH}_{3} \mathrm{OH}, \Delta \varepsilon\right) 193(-1.3), 217(+16.1), 262(+3.3) \mathrm{nm} ; \mathrm{IR}$ (KBr) $v_{\max } 3499,2989,1737,1641,1374,1247,1023 \mathrm{~cm}^{-1}$; Negative ESI-

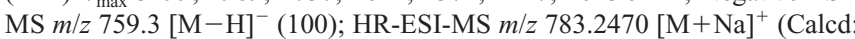
$\left.\mathrm{C}_{37} \mathrm{H}_{44} \mathrm{O}_{17} \mathrm{Na}, 783.2471\right) ;{ }^{1} \mathrm{H}$ - and ${ }^{13} \mathrm{C}-\mathrm{NMR}$ data, see Tables 1 and 2.

Tabulalide $\mathrm{G}(2)$ : White amorphous powder; $[\alpha]_{\mathrm{D}}^{25}+61 \quad(c=0.20$, $\left.\mathrm{CH}_{3} \mathrm{OH}\right) ; \mathrm{CD}\left(\mathrm{CH}_{3} \mathrm{OH}, \Delta \varepsilon\right) 192(-0.5), 215(+17.5), 262(+3.2) \mathrm{nm} ; \mathrm{CD}$ $\left(\mathrm{CH}_{3} \mathrm{CN}, \Delta \varepsilon\right) 190(\Delta \varepsilon-3.1), 216(+15.1), 266(+2.5) \mathrm{nm}$; IR $(\mathrm{KBr}) v_{\max }$ 3486, 2971, 1736, 1644, 1374, 1224, $1042 \mathrm{~cm}^{-1}$; Negative ESI-MS $\mathrm{m} / \mathrm{z}$ $801.3 \quad[\mathrm{M}-\mathrm{H}]^{-}$(100); HR-ESI-MS $m / z \quad 825.2563 \quad[\mathrm{M}+\mathrm{Na}]^{+}$(Calcd: $\left.\mathrm{C}_{39} \mathrm{H}_{46} \mathrm{O}_{18} \mathrm{Na}, 825.2576\right) ;{ }^{1} \mathrm{H}$ - and ${ }^{13} \mathrm{C}-\mathrm{NMR}$ data, see Tables 1 and 2.

Tabulalide $\mathrm{H}(\mathbf{3})$ : White amorphous powder; $[\alpha]_{\mathrm{D}}^{25}-25.8 \quad(c=0.18$, $\left.\mathrm{CH}_{3} \mathrm{OH}\right)$; IR ( $\left.\mathrm{KBr}\right) v_{\max } 3452,1736,1640,1367,1267,1035 \mathrm{~cm}^{-1}$; Negative ESI-MS $m / z 653.4[\mathrm{M}+\mathrm{Cl}]^{-}(100)$; HR-ESI-MS $m / z$ 641.1843 [M+Na] ${ }^{+}$ (Calcd: $\mathrm{C}_{30} \mathrm{H}_{34} \mathrm{O}_{14} \mathrm{Na}, 641.1841$ ); ${ }^{1} \mathrm{H}$ - and ${ }^{13} \mathrm{C}-\mathrm{NMR}$ data, see Tables 1 and 2.

Tabulalide I (4): White amorphous powder; $[\alpha]_{\mathrm{D}}^{25}-30.8 \quad(c=0.13$, $\mathrm{CH}_{3} \mathrm{OH}$ ); IR (KBr) $v_{\max } 3457,1738,1641,1368,1222,1046 \mathrm{~cm}^{-1}$; Negative ESI-MS $m / z 695.4[\mathrm{M}+\mathrm{Cl}]^{-}(100)$; HR-ESI-MS $m / z 683.1944[\mathrm{M}+\mathrm{Na}]^{+}$ (Calcd: $\mathrm{C}_{32} \mathrm{H}_{36} \mathrm{O}_{15} \mathrm{Na}, 683.1946$ ); ${ }^{1} \mathrm{H}$ - and ${ }^{13} \mathrm{C}-\mathrm{NMR}$ data, see Tables 1 and 2.

Tabulalide J (5): White amorphous powder; $[\alpha]_{\mathrm{D}}^{25}-19.9(c=0.14$, $\mathrm{CH}_{3} \mathrm{OH}$ ); IR (KBr) $v_{\max } 3467,1744,1639,1372,1236,1026 \mathrm{~cm}^{-1}$; Negative ESI-MS $m / z 695.4[\mathrm{M}+\mathrm{Cl}]^{-}$(100); HR-ESI-MS $m / z 683.1948[\mathrm{M}+\mathrm{Na}]^{+}$ (Calcd: $\left.\mathrm{C}_{32} \mathrm{H}_{36} \mathrm{O}_{15} \mathrm{Na}, 683.1946\right) ;{ }^{1} \mathrm{H}$ - and ${ }^{13} \mathrm{C}-\mathrm{NMR}$ data, see Tables 1 and 2.

Tabulalide $\mathrm{K}(\mathbf{6})$ : White amorphous powder; $[\alpha]_{\mathrm{D}}^{25}-59.1 \quad(c=0.18$, $\mathrm{CH}_{3} \mathrm{OH}$ ); IR (KBr) $v_{\max } 3528,1743,1634,1374,1242,1036 \mathrm{~cm}^{-1}$; Negative ESI-MS $m / z 817.3[\mathrm{M}-\mathrm{H}]^{-}(100)$; HR-ESI-MS $m / z 841.2509[\mathrm{M}+\mathrm{Na}]^{+}$ (Calcd: $\mathrm{C}_{39} \mathrm{H}_{46} \mathrm{O}_{19} \mathrm{Na}, 841.2526$ ); ${ }^{1} \mathrm{H}$ - and ${ }^{13} \mathrm{C}-\mathrm{NMR}$ data, see Table 3 .
Tabulalide L (7): White amorphous powder; $[\alpha]_{\mathrm{D}}^{25}-54.9(c=0.16$, $\left.\mathrm{CH}_{3} \mathrm{OH}\right)$; IR (KBr) $v_{\max } 3451,1747,1641,1372,1234,1034 \mathrm{~cm}^{-1}$; Negative ESI-MS $m / z$ 836.3 [M+NH $]^{+}(100)$; HR-ESI-MS $m / z 841.2529[\mathrm{M}+\mathrm{Na}]^{+}$ (Calcd: $\left.\mathrm{C}_{39} \mathrm{H}_{46} \mathrm{O}_{19} \mathrm{Na}, 841.2526\right) ;{ }^{1} \mathrm{H}$ - and ${ }^{13} \mathrm{C}$-NMR data, see Table 3 .

Tabulalide M (8): White amorphous powder; $[\alpha]_{\mathrm{D}}^{25}-55.8(c=0.14$, $\left.\mathrm{CH}_{3} \mathrm{OH}\right)$; IR (KBr) $v_{\max } 3525,1733,1638,1320,1244,1034 \mathrm{~cm}^{-1}$; negative ESI-MS $m / z 779.2[\mathrm{M}+\mathrm{Cl}]^{-}(100)$; HR-ESI-MS $m / z 757.2324[\mathrm{M}+\mathrm{Na}]^{+}$ (Calcd: $\left.\mathrm{C}_{35} \mathrm{H}_{42} \mathrm{O}_{17} \mathrm{Na}, 757.2314\right) ;{ }^{1} \mathrm{H}$ - and ${ }^{13} \mathrm{C}$-NMR data, see Table 3 .

Tabulalide N (9): White amorphous powder; $[\alpha]_{\mathrm{D}}^{25}-56.8(c=0.13$, $\left.\mathrm{CH}_{3} \mathrm{OH}\right)$; IR (KBr) $v_{\max } 3429,1725,1640,1365,1240,1040 \mathrm{~cm}^{-1}$; negative ESI-MS $m / z$ 747.2 [M-Hl] ${ }^{-}(100)$; HR-ESI-MS $m / z$ 771.2466 [M+Na] ${ }^{+}$ (Calcd: $\left.\mathrm{C}_{36} \mathrm{H}_{44} \mathrm{O}_{17} \mathrm{Na}, 771.2471\right) ;{ }^{1} \mathrm{H}$ - and ${ }^{13} \mathrm{C}-\mathrm{NMR}$ data, see Table 3 .

Cytotoxicity Bioassays Compounds 2-12 were evaluated for cytotoxic activity against MCF-7 (human breast cancer), Hela (human cervical cancer), SGC-7901 and BGC-823 (human gastric cancer), HepG2 (human liver cancer), cells by a MTT assay as described in the literature. ${ }^{17)}$ The cells were obtained from the Cell Bank of the Shanghai Institute of Cell Biology. Taxol was used as a positive control, and the experiments were conducted for three independent replicates.

Acknowledgements This research work was supported by the Key Project of National Natural Science Foundation of China (Grant No. 30830116) and the National Key Scientific and Technological Special Projects (2009ZX09502-011) of China.

\section{References}

1) Taylor D. A. H., "Progress in the Chemistry of Organic Natural Products," Vol. 45, ed. by Herz W., Grisebach H., Kirby G. W., SpringerVerlag, New York, 1984, pp. 1-102.

2) Liao S. G., Chen H. D., Yue J. M., Chem. Rev., 109, 1092-1140 (2009).

3) Kaur R., Arora S., J. Med. Plants Res., 3, 196-216 (2009)

4) Ragettli T., Tamm C., Helv. Chim. Acta, 61, 1814-1831 (1978).

5) Connolly J. D., Labbe C., Rycroft D. S., J. Chem. Soc., Perkin Trans. I, 1978, 285-288 (1978).

6) Nakatani M., Abdelgaleil S. A. M., Saad M. M. G., Huang R. C., Doe M., Iwagawa T., Phytochemistry, 65, 2833-2841 (2004).

7) Fan C. Q., Wang X. N., Yin S., Zhang C. R., Wang F. D., Yue J. M., Tetrahedron, 63, 6741-6747 (2007).

8) Zhang C. R., Yang S. P., Zhu Q., Liao S. G., Wu Y., Yue J. M., J. Nat Prod., 70, 1616-1619 (2007).

9) Zhang C. R., Yang S. P., Chen X. Q., Wu Y., Zhen X. C., Yue J. M., Helv. Chim. Acta, 91, 2338-2350 (2008).

10) Luo J., Wang J. S., Luo J. G., Wang X. B., Kong L. Y., Org. Lett., 11, $2281-2284$ (2009).

11) Luo J., Wang J. S., Wang X. B., Luo J. G., Kong L. Y., J. Nat. Prod., 73, 835-843 (2010)

12) Luo J., Wang J. S., Wang X. B., Huang X. F., Luo J. G., Kong L. Y., Tetrahedron, 65, 3425-3431 (2009).

13) Wu J., Xiao Q., Zhang S., Li X., Xiao Z. H., Ding H. X., Li Q. X., Tetrahedron, 61, 8382-8389 (2005).

14) Roy A., Saraf S., Biol. Pharm. Bull., 29, 191-201 (2006).

15) Brandt G. E. L., Schmidt M. D., Prisinzano T. E., Blagg B. S. J., J. Med. Chem., 51, 6495-6502 (2008).

16) Cui J. X., Deng Z. W., Li J., Fu H. Z., Proksch P., Lin W. H., Phytochemistry, 66, 2334-2339 (2005).

17) Lu Y. Y., Luo J. G., Huang X. F., Kong L. Y., Steroids, 74, 95-101 (2009). 